DOI: $10.19195 / 0524-4544.326 .20$

\author{
MATEUSZ PAPLICKI \\ ORCID: 0000-0002-4169-9298 \\ Uniwersytet Medyczny
}

\title{
Sprawozdanie z konferencji „Ochotnicze straże pożarne — tradycja, samorząd, bezpieczeństwo"
}

Dnia 11 czerwica 2018 roku na Wydziale Prawa Administracji i Ekonomii Uniwersytetu Wrocławskiego odbyła się konferencja naukowa poświęcona ochotniczym strażom pożarnym, zatytułowana „Ochotnicze straże pożarne — tradycja, samorząd, bezpieczeństwo". Celem konferencji było omówienie sytuacji prawnej i organizacyjnej ochotniczych straży pożarnych, jednostek organizacyjnych o statusie stowarzyszenia, czyli dobrowolnych, samorządnych, trwałych zrzeszeń o celach niezarobkowych, mających wszakże status jednostek ochrony przeciwpożarowej, czyli jednostek realizujących przedsięwzięcia mające na celu ochronę życia, zdrowia, mienia lub środowiska przed pożarem, klęską żywiołową lub innym miejscowym zagrożeniem. Ochotnicza straż pożarna należy zatem do jednostek umundurowanych, dysponujących specjalistycznym sprzętem, w który wyposaża je gmina.

To powoduje, że ochotnicze straże pożarne (dalej: OSP) są specyficznymi stowarzyszeniami, których sytuacja prawna i organizacyjna różni się od pozostałych jednostek posiadających status stowarzyszenia. Jako jednostka ochrony przeciwpożarowej OSP może być także włączona do krajowego systemu ratowniczo-gaśniczego, co wymaga specjalistycznego wyszkolenia. Członkowie OSP biorący udział $\mathrm{w}$ akcjach powinni spełnić warunki przewidziane w przepisach ustawy przeciwpożarowej. Stąd też pytanie o status OSP i jej członków oraz jaką rolę społeczną jednostki ochrony przeciwpożarowej pełnią $\mathrm{w}$ realizacji przedsięwzięć związanych z zapewnieniem bezpieczeństwa.

Organizatorem konferencji był Instytut Nauk Administracyjnych Wydziału Prawa, Administracji i Ekonomii Uniwersytetu Wrocławskiego przy współudzia- 
le Stowarzyszenia Absolwentów Wydziału Prawa, Administracji i Ekonomii Uniwersytetu Wrocławskiego „Uniwersytecka” oraz Urzędu Marszałkowskiego Województwa Dolnośląskiego. Organizowana konferencja jest już kolejną z cyklu konferencją na temat szeroko pojętego bezpieczeństwa. Zrealizowano ją dzięki Urzędowi Marszałkowskiemu Województwa Dolnośląskiego oraz pasjonatom ze Straży Pożarnej — zarówno ochotniczej, jak i zawodowej.

Dyrektor Instytutu Nauk Administracyjnych profesor UWr dr hab. Tadeusz Kocowski otworzył konferencję i powitał przybyłych gości. Uświetnił ją swoją obecnością i wygłosił słowo wstępne JM Rektor Uniwersytetu Wrocławskiego profesor Adam Jezierski. Głos zabrali także przedstawiciele władz rządowych i samorządowych: przewodniczący Sejmiku Dolnośląskiego Paweł Wróblewski, dyrektor Wydziału Bezpieczeństwa i Zarządzania Kryzysowego Grzegorz Sudjak, a także dziekan Wydziału Prawa, Administracji i Ekonomii Uniwersytetu Wrocławskiego profesor Karol Kiczka, który podczas swojego wystąpienia podziękował za organizację konferencji i za zajęcie się tak ważną tematyką zarówno dla społeczeństwa, jak i administracji publicznej.

Merytorycznie konferencja została podzielona na trzy części. W pierwszej zatytułowanej „Ochotnicze Straże pożarne jako stowarzyszenia” moderatorem był profesor Uniwersytetu Mikołaja Kopernika (UMK) dr hab. Henryk Nowicki, a referaty wygłosili:

— Zbigniew Szczygieł, Sejmik Województwa Dolnośląskiego, referat Dziatania Samorządu Województwa na rzecz ochotniczych straży pożarnych;

— profesor UWr dr hab. Tadeusz Kocowski, referat OSP jako stowarzyszenie działajace w gminie;

— dr Maciej Błażewski, referat Prawne aspekty finansowania przez gmine działalności OSP;

- Adam Górecki, wójt gminy Czarny Bór, referat Funkcjonowanie ochotniczych straży pożarnych $w$ Gminie Czarny Bór;

- Maciej Gałęski, Euroregion Nysa, referat Wpływ ochotniczych straży pożarnych na poziom kultury bezpieczeństwa ekologicznego;

— st. bryg. w st. sp. mgr Andrzej Jaroszek, referat Status stużbowy strażaka zawodowego PSP oraz strażaka ratownika OSP;

- Dariusz Gortych, referat Wybrane elementy z historii OSP.

W drugiej części zatytułowanej „Ochotnicza straż pożarna a działania i akcje ratownicze" moderatorem był profesor UWr dr hab. Tadeusz Kocowski, a referaty wygłosili:

— profesor UMK dr hab. Henryk Nowicki, referat OSP jednostka ochrony przeciw pożarowej; niczej;

— dr Joanna Filaber, referat PSP $w$ organizacji i prowadzeniu akcji ratow-

- Grzegorz Duda, wicestarosta milicki, referat OSP w KSRG powiatu milickiego; 
— mgr Mateusz Paplicki, referat Czy OSP może nie wyjechać do działań ratowniczych?;

- mgr Jakub Czudiak, referat KSRG w zarzadzaniu kryzysowym;

— mł. bryg. mgr inż. Jerzy Ciężki, referat Organizacja szkolenia dla OSP;

- Maciej Nebelski, referat Strategia systemu teleinformatrycznego w systemie bezpieczeństwa;

— st. bryg. mgr inż. Adam Konieczny, referat Przyszłość ochotniczych straży Pożarnych.

Wygłoszone referaty wywołały ożywioną dyskusję, w której głos zabrali między innymi: Ryszard Dąbrowa — przedstawiciel Zarządu Krajowego Związku Ochotniczych Straży Pożarnych Rzeczypospolitej Polskiej, Adam Konieczny — Wojewódzki Komendant Straży Pożarnej czy przedstawiciele ochotniczych straży pożarnych reprezentujący jednostki z całego kraju.

Tego samego dnia na Wydziale Prawa, Administracji i Ekonomii Uniwersytetu Wrocławskiego odbyła się trzecia część konferencji pod tytułem „Ochotnicze straże pożarne - uwarunkowania prawne", której moderatorem była Aleksandra Oślizło. Tę część konferencji zorganizowali doktoranci oraz studenci Wydziału pod kierunkiem dr. Macieja Błażewskiego. Doktor Błażewski otworzył konferencję oraz oddał głos licznie przybyłym prelegentom z ośrodków naukowych z całego kraju. Wygłoszono czternaście referatów.

W konferencji wzięło udział około stu osób, które wyraziły potrzebę kontynuowania badań nad poruszaną tematyką. Konferencja stanowiła jeden z elementów współpracy z Urzędem Marszałkowskim w obszarze bezpieczeństwa. Dzięki niej 24 kwietnia 2018 roku między Urzędem a Wydziałem została podpisana umowa przewidująca organizację podmiotowej konferencji oraz wydanie dwóch publikacji, w tym jednej w formie elektronicznej, która zawierać będzie raport Ochotnicze straże pożarne — zadania - samorzą - bezpieczeństwo. W celu opracowania raportu dziekan Wydziału Prawa, Administracji i Ekonomii UWr dnia 5 czerwca 2018 roku podjął decyzję o powołaniu zespołu badawczego w składzie: kierownik - prof. nadzw. UWr dr hab. Tadeusz Kocowski oraz dr Joanna Filaber, dr Maciej Błażewski, mgr Stanisław Ręcławowicz, mgr Andrzej Jaroszek oraz mgr Mateusz Paplicki. 